\title{
THE STRATIFIED SLOPE DEPOSITS OF TIERRA DEL FUEGO (ARGENTINA) AS AN ANALOGUE FOR SIMI- LAR PLEISTOCENE DEPOSITS IN GALICIA (NW SPAIN)
}

\author{
Augusto PÉREZ ALBERTI (augusto.perez@usc.es) \\ Laboratorio de Tecnología Ambiental, Universidad de Santiago de \\ Compostela \\ Pedro P.CUNHA (pcunha@dct.uc.pt) \\ Marine and Environmental Sciences Centre, Department of Earth Sciences, \\ Universidade de Coimbra
}

Recibido: $11 / 02 / 2016$

Aceptado: 18/04/2016

ABSTRACT: This paper focuses on slope dynamics in schist/slate materials in cold humid environments. It characterises the sedimentological features and controls involved in the formation of stratified slope deposits in two areas with similar topographical, lithological and climatic characteristics. In both areas, the slopes have dips $>30^{\circ}$ and the dominant rock types are schists and slates. In the case of Tierra del Fuego, the sedimentary deposits studied are modern; those in Galicia are Pleistocene in age. The slope processes operating in Tierra del Fuego, generating modern stratified slope sedimentary deposits, throw light upon the interpretation of similar ancient sediments studied in Galicia. This comparative study reveals the fundamental role played by snow and freeze-thaw cycles in the creation of stratified slope deposits. Firstly, snow cover has a direct effect on the slope, compacting sediments, keeping ground temperature stable during winter, or moving clasts as they slip down the slope or act as a slide ramp. Indirectly, as the snow melts, it creates surface run-off and mud or gravel slides. Secondly, the activity generated by numerous freeze-thaw cycles results in the vertical mobility of clasts. However, the continuous loading of sediments on the slope hinders the formation of coarse-grained pavement. Thirdly, the rock type and slope steepness play an important role in the creation of stratified slope deposits.

KEY WORDS: Stratified slope deposits, cryonival processes, Fuegian Andes, Argentina, Serra do Courel, Galicia, Spain.

LOS DEPÓSITOS DE LADERA ESTRATIFICADOS DE TIERRA DEL FUEGO (ARGENTINA) COMO ANALOGO PARA DEPÓSITOS PLEISTOCENOS SIMILARES EN GALICIA (NW SPAIN)

RESUMEN: El presente artículo se centra en analizar la dinámica de las laderas modeladas sobre materiales esquisto pizarrosos en ambientes fríos y húmedos. Se describen las características sedimentológicas y los controles que colaboran en la formación de depósitos de pendiente estratificados en dos áreas con características topográficas, litológicas y climáticas similares. En ambas áreas, las laderas presentan pendientes que superan los $30^{\circ}$ de inclinación y los tipos 
de rocas dominantes son esquistos y pizarras. En el caso de Tierra del Fuego, los depósitos sedimentarios estudiados son modernos. Los de la Serra do Courel en Galicia se han acumulado durante las fases frías del Pleistoceno. Los procesos de ladera que operan en Tierra del Fuego, la generación de depósitos sedimentarios estratificados en la actualidad, arrojan luz sobre la interpretación de los sedimentos antiguos similares existentes en Galicia. El análisis comparativo revela el papel fundamental que desempeñan/desempeñaron los ciclos de nieve y hielodeshielo en la creación de depósitos. En primer lugar, la capa de nieve tiene un efecto directo sobre la ladera al compactar los sedimentos, por colaborar en el mantenimiento de la temperatura del suelo estable durante el invierno y por facilitar el movimiento de los clastos ladera abajo. De manera indirecta, al derretirse, genera una escorrentía superficial que provoca regueros y coladas de barro o de grava. En segundo lugar, la actividad generada por numerosos ciclos de congelación-descongelación ha dado lugar a la movilidad vertical de los clastos. Sin embargo, la carga continua de sedimentos en la pendiente dificulta la formación de pavimentos de grano grueso. En tercer lugar, el tipo de roca y la pendiente juegan un papel importante en la creación de derrubios estratificados.

PALABRAS CLAVE: derrubios estratificados de ladera, procesos crionivales, Andes Fueguinos, Argentina, Serra do Courel, Galicia; España.

\section{INTRODUCTION}

Stratified screes, originally termed grèzeslitées, are sedimentary deposits displaying a vertical sequence of levels that parallel the slope, with a prevalence of numerous thin and flat clasts. Their study, within the framework of slope evolution in cold environments, has generated interest from a large number of researchers (e.g. CAILLEUX, 1948; GUILLIEN, 1951, 1962; MALAURIE y GUILliEN 1953; DYLIK, 1967; KIRKBY y STATHAM, 1975; JOURNAUX, 1976; VAN STEIJN et al., 1984; FRANCOU, 1989, 1990; DEWOLF, 1987; FRANCOU y HETU, 1989; NIEUWENHUIJZEN y VAN STEIJN, 1990; BERTRAN et al., 1992, 1995; BERTRAND et al., 1994; OzOUF et al., 1993, 1995; HETU, 1995; Hetu et al., 1995; VAN STEIJN et al., 1995; PAPPALARDO, 1999; BERTRAN y TEXIER, 2000; GENGNIAN et al., 1999; FRENCH, 2000, 2007; HARRIS y PRICK, 2000; GARCÍA RUIZ et al., 2001; TEXIER y MEIRELES, 2003. However, in the last decade few papers focused on stratified slope deposits (e.g. De Blasio y SAeter, 2009; VAN Stejn, 2011).

Regardless of whether they concern ancient or modern deposits, the majority of publications deal with stratified slope sediments in areas where climate is characterised by a moisture deficit (e.g., the Mediterranean region or dry Andes) and raise serious doubts concerning the mechanisms that control slope dynamics and associated sedimentary deposits. However, many studies of active stratified slope deposits have been made in cold humid environments, for example the stone-banked solifluction lobes in the Alps (mean annual precipitation $\sim 1.500 \mathrm{~mm}$ ) (VAN STEJN et al., 1995; BERTRAN et al., 1995), and the combination of creep, snow avalanches and frost-coated clast flows in Gaspésie (HeTU, 1995). 
Following an initial contribution by PÉREZ ALBERTI (2012), the objective of this paper is to present the sedimentological features and controls involved in the formation of stratified slope deposits in two areas with similar topographical, lithological and climatic characteristics, namely in which humidity is, or has been, a major player: (i) the Sierra Alvear study area, in Tierra del Fuego (Argentina), where the current climate regime is cold and humid; and (ii) the Serra do Courel study area, in Galicia (Spain), that nowadays has a temperate and humid climate but, according to available data (PÉREZ ALBERTI, 1979; PÉREZ AlBERTI et al., 2009), was subject to cold and humid conditions during the Late Weichselian (the last glacial period of Late Pleistocene). Tierra del Fuego is used as a modern analogue for the climate regime that prevailed in Galicia during this last cold period. In Tierra del Fuego, the vegetation-free environment allowed observation of the slope deposits by the opening of trenches. In Galicia, exposures are scarce and analysis depended largely on exposures created by fluvial incision or civil engineering works.

The hypotheses that need to be clarified are: 1) that the lithological and structural characteristics of the source rocks could play a major role in clast genesis under cold and humid climate conditions; 2) that a significant quantity of clay fraction could be produced by chemical weathering under cold and humid climate conditions; and 3) that topographical factors, such as slope dip and exposure, are of relevance in explaining differences in the sedimentary processes and depositional sequences on slopes. The further research questions addressed are: 4) what is the relevance of climatic factors, in the form of temperature variability at both air and ground level?; 5) what are the typical characteristics of stratified slope deposits generated in a cold and humid climate?; and 6) can ancient stratified slope deposits be identified?

\section{METHODS}

The various geomorphological units were differentiated by the use of digital terrain models (DTM) produced by the ArcGis 10.3 suite. In order to compare the two study areas, we used a DEM with $30 \mathrm{~m}$ resolution (ASTER).

GPS mapping in the Sierra Alvear study area was performed in order to identify the main cold-climate features of the ground (VALCÁRCEL et al., 2006). These were later monitored (PÉREZ ALBERTI et al., 2007) in order to obtain the thermal response of the ground. Several thermal monitoring stations were set up and equipped with HOBO U12, Pendant and Micro Station data loggers. A CALM (Circum-polar Active Layer Monitoring) plot, measuring $80 \times 80 \mathrm{~m}$, was also established in a level sector located $1050 \mathrm{~m}$ a.s.l. Other

plots were also marked out into which stakes of differing lengths $(50,40,30$, 
$20,10 \mathrm{~cm})$ and thicknesses $(2 \times 2 \mathrm{~cm}, 1 \times 1 \mathrm{~cm}, 8 \times 8 \mathrm{~mm})$ were inserted in order to determine frost heave activity.

In the Sierra Alvear, 6 trenches c. $1.5 \mathrm{~m}$ deep were made to provide observation of the sedimentary deposits. In the Sierra do Courel, observations were made in outcrops c. $2.0 \mathrm{~m}$ high located along roads in A Seara and Toca sites. In the more representative outcrops, sedimentary samples were collected from the finer gravel layers, c. $500 \mathrm{~g}$ each and only with particle sizes $<11 \mathrm{~mm}$.

At the outcrops, the depositional facies were characterised. On each stratigraphic level, the maximum, mean and minimum axes of 50 clasts were measured in order to determine central-tendencies and dispersion parameters as well as flatness and oblate-prolate indices. The outcrops also document vertical clasts that appear to have been expelled as a result of frost activity.

Samples were collected for laboratory analysis - 12 samples from the Sierra Alvear study area (Tristénsite - 7 samples; Alvear 2 site - 5 samples) and 23 samples from the Serra do Courel study area (Seara 2 site -10 samples and Toca site -13 samples) respectively.

The $11 \mathrm{~mm}-63 \mu \mathrm{m}$ fraction was subjected to sieving (column with a $1 / 2 \varnothing$ interval). The fine fraction ( $<63 \mu \mathrm{m}$, comprising silt and clay) was analysed with a Beckman-Coulter LS230 laser granulometre (2000 to $0.04 \mu \mathrm{m})$. The grain-size distribution of each selected sample was obtained by the integration of results provided by the two methods. Graphic statistical parameters (mean, standard deviation, skewness and kurtosis) were used to characterise the sediments and their depositional processes.

Identification of clay minerals in the sedimentary deposits, in 11 samples of the Sierra Alvear area and 17of the Serra do Courel area, was made by X-Ray Diffraction analysis of the $<2 \mu \mathrm{m}$ fraction.

\section{REGIONAL BACKGROUND OF THE TWO STUDY AREAS III.1. Sierra Alvear study area, Tierra del Fuego}

III.1.a. Geomorphological setting

Tierra del Fuego lies at the southernmost tip of South America (FIGURE 1). Geomorphologically, the Fuegian Andes run from west to east, their profile being the result of strike-slip faults (MENICHETTI et al., 2008). Broad valleys elongated west-east mark the relief structure: Lake Fagnano, to the north, Tierra Mayor to the south and the Beagle Channel even further to the south 
are the most characteristic. A large number of smaller valleys trend perpendicular to these main valleys, the result being a relief consisting of broad valleys and narrow crests joined by slopes whose gradient can exceed $30^{\circ}$.

The sector selected for our research lies in the Sierra Alvear, between 800 $\mathrm{m}$ and $1050 \mathrm{~m}$ a.s.l. It is bounded on the north by the headwaters of the Río Alvear, on the east, by those of the Río Tristén, on the south by the Las Cotorras valley, and on the west by the peaks of Pico Alvear.

Figure 1. Location of the Sierra Alvear study area, in Tierra del Fuego.

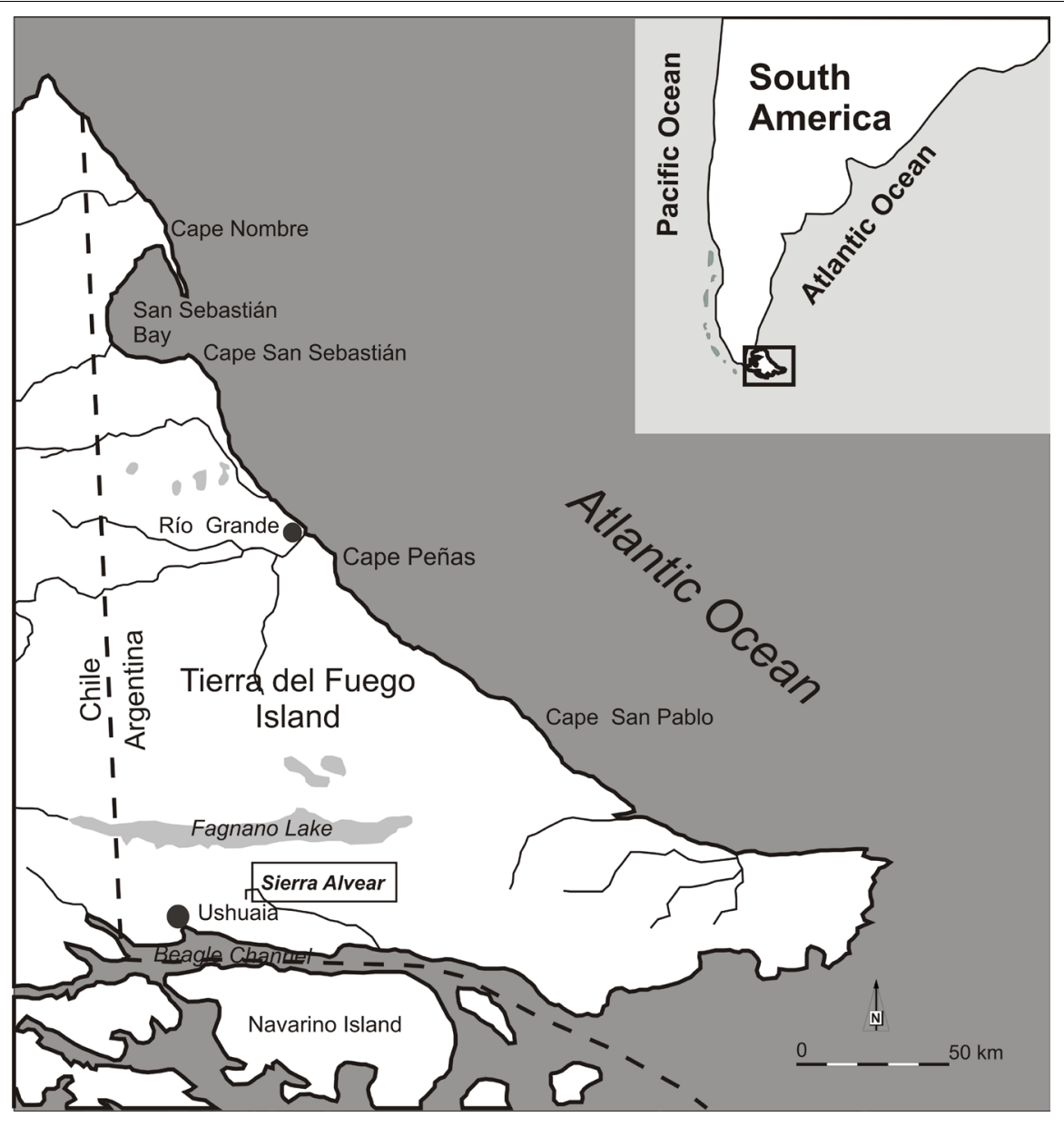

The Sierra Alvear contains slopes oriented in all directions. A detailed study reveals (FIGURE 2) that $24 \%$ of the maximum slope angles are between $10^{\circ}$ 
and $20^{\circ} ; 19 \%$ are between $20^{\circ}-30^{\circ}$; and $9 \%$ are in excess of $30^{\circ}$ in angle. Also noteworthy is that $21 \%$ of the slopes are north-facing, $23 \%$ south-facing, $18 \%$ west-facing and $20 \%$ east-facing. When slope and direction data are contrasted, we find, for example, that $2 \%$ of the north-facing terrain has a slope of $20^{\circ}-30^{\circ}$, while for the same gradient, $5 \%$ of the terrain is south-facing.

Figure 2. Topographical factors in the Sierra Alvear study area, Tierra del Fuego: (a) Slopes; (b) Orientations (expositions).

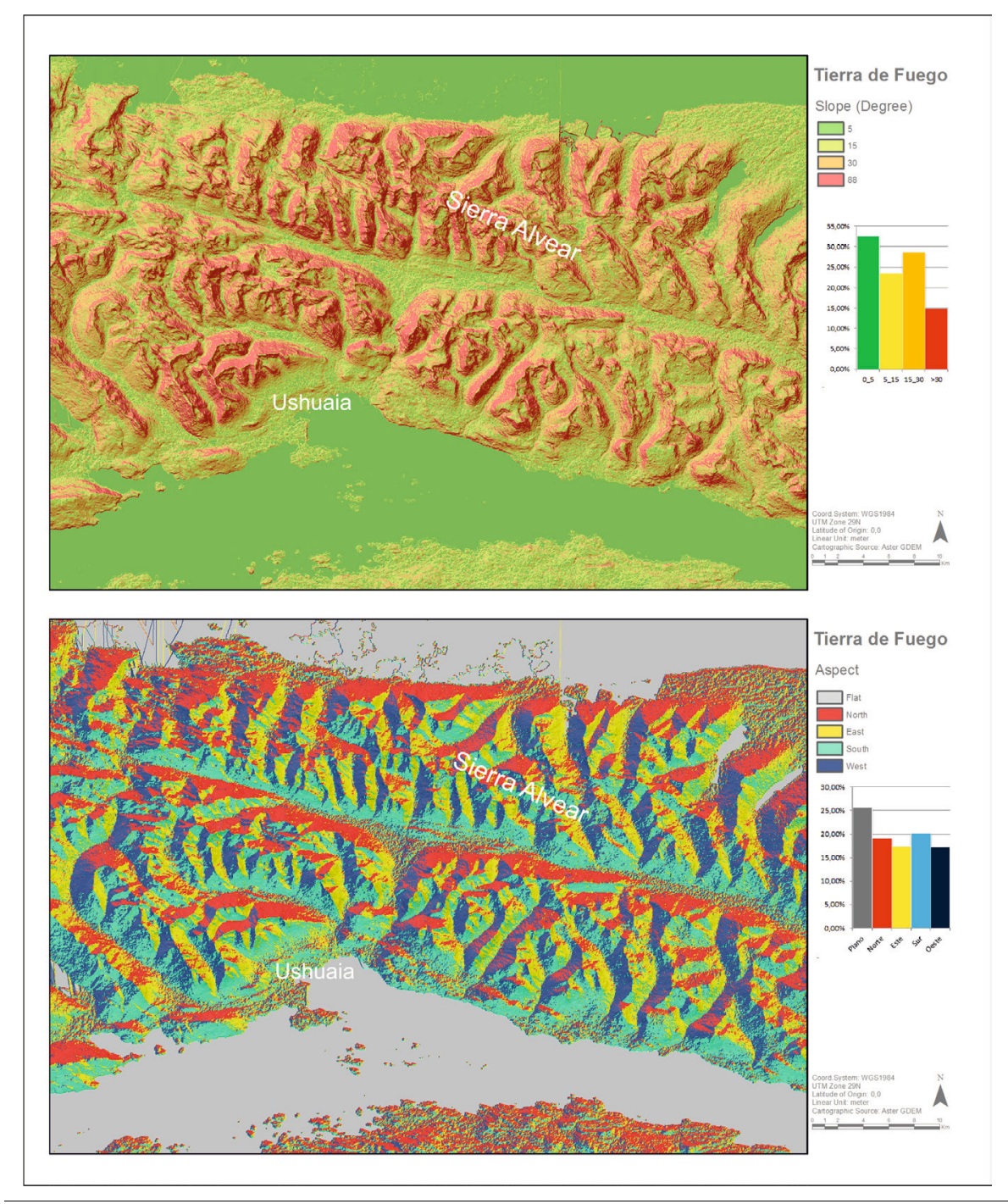


Figure 3. Air and ground temperatures in Sierra Alvear (Tierra del Fuego).

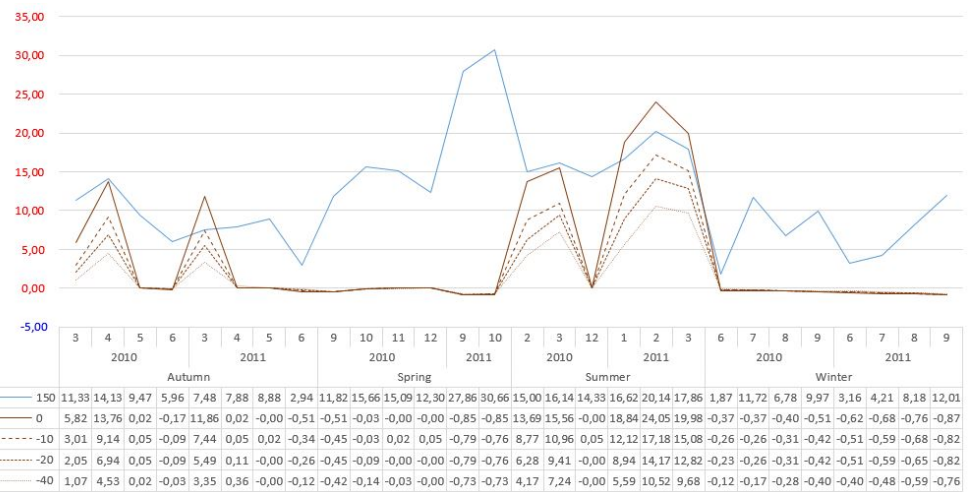

\section{A - Maximun temperature}

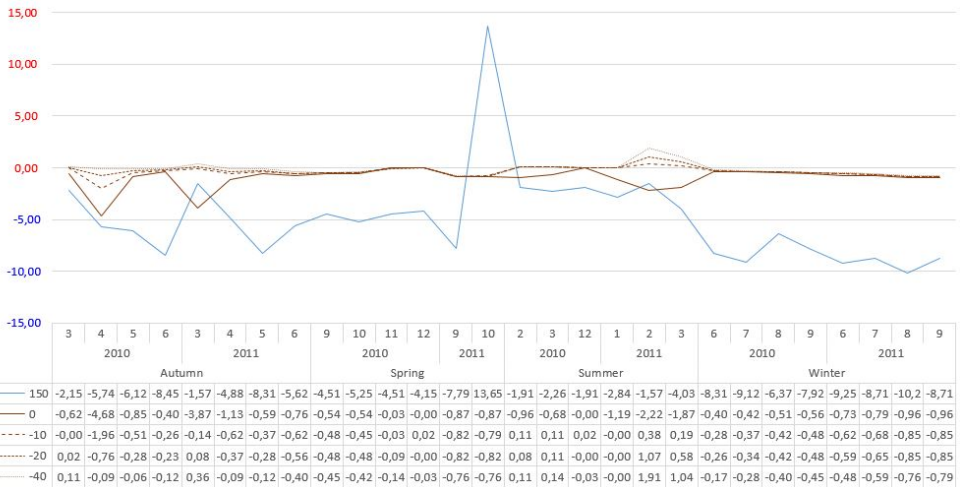

\section{B - Minimum temperature}

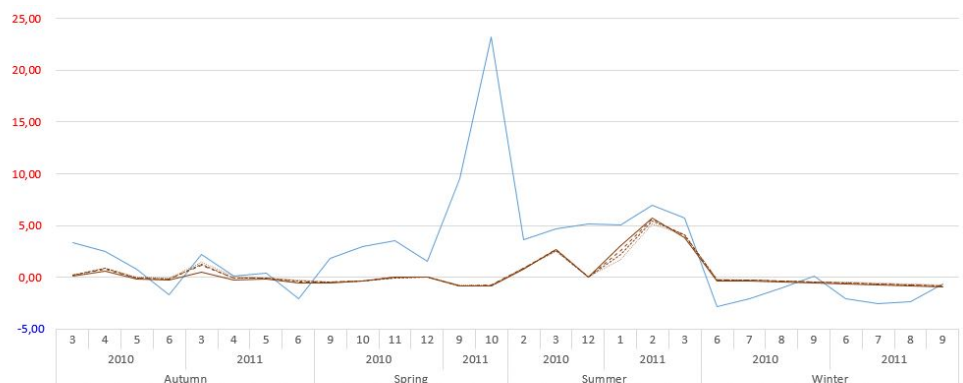

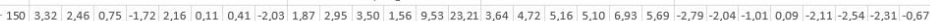

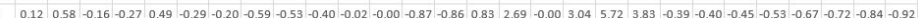

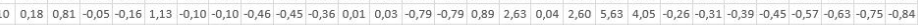

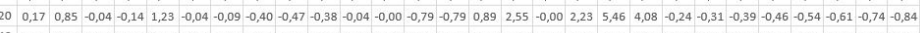

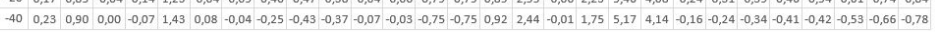

\section{C- Mean temperature}


At the heads of N-S valleys, there are divides where the slope varies; transversally, there are sectors that are practically flat while others have gradients $>40^{\circ}$. Longitudinally, towards the north, slopes have gradients of $15-20^{\circ}$ while towards the south, they gradually increase to $30^{\circ}$. In the study area, the dominant rocks are porphyry basalts and slates, defined by Olivero and Martinioni (2001) as the Lemaire Formation (Upper Jurassic).

\section{III.1.b. Climate}

The climate is temperate-cold and humid, with a strong and markedly seasonal oceanic influence (TUHKANEN, 1992). There are no rainfall data but at Ushuaia, close to sea level, the mean annual rainfall for the 1961-1970 period was $550 \mathrm{~mm}$ (Linares, 1984). Mean air temperature recorded in this study area, at $1050 \mathrm{~m}$ a.s.1., between February 2005 and January 2010 , was $-1.9^{\circ} \mathrm{C}$, with a maximum of $12.5^{\circ} \mathrm{C}$ and a minimum of $-12.8^{\circ} \mathrm{C}$ (FIGURE $3 \mathrm{~A}$ ).

At Tristén River valley, c. $817 \mathrm{~m}$ a.s.1., the air temperatures recorded during the years 2010 to 2012 can be characterised as: a maximum value of $30.65^{\circ} \mathrm{C}$, a minimum of $-10.21^{\circ} \mathrm{C}$ and a mean of $1.75^{\circ} \mathrm{C}$. During the same period, the ground temperatures also ranged at several depths:

- At0 cm, a maximum of $27.40^{\circ} \mathrm{C}$, a minimum of $-5.51{ }^{\circ} \mathrm{C}$ and a mean of $0.89^{\circ} \mathrm{C}$;

- At $10 \mathrm{~cm}$, a maximum of $17.17^{\circ} \mathrm{C}$, a minimum of $-1.95^{\circ} \mathrm{C}$ and a mean of $0.88^{\circ} \mathrm{C}$;

- At $20 \mathrm{~cm}$, a maximum of $14.17^{\circ} \mathrm{C}$, a minimum of $0.84^{\circ} \mathrm{C}$ and a mean of $0.84{ }^{\circ} \mathrm{C}$;

- At $40 \mathrm{~cm}$, a maximum of $10.51^{\circ} \mathrm{C}$, a minimum of $-0.78{ }^{\circ} \mathrm{C}$ and a mean of $0.81^{\circ} \mathrm{C}$.

The annual ground temperature regime reflects two distinct periods: one during the equinoctial seasons (spring and summer), during which temperature variability range increases, with frequent cycles with temperatures above and below $0{ }^{\circ} \mathrm{C}$; the other, during autumn and winter, when variability is lower and temperatures remain below $0^{\circ} \mathrm{C}$. Thermal stability is favoured by the presence of a snow cover.

\section{III.2. Serra do Courel study area, Galicia (Spain)}

\section{III.2.a. Geomorphological setting}

Galicia is located at the NW border of Iberia, facing the Atlantic Ocean. Geomorphologically, in Galicia a clear altitudinal zonation of landforms exists (PÉREZ ALBERTI, 1982), their profile being mainly the result of strike-slip faults (PÉREZ ALBERTI, 1993; DE VICENTE et al., 2011). The relief of the 
Serra do Courel (FIGURE 4) is characterised by sets of valleys and narrow ridges shaped by rivers: the Lor, to the north, Quiroga, in the centre, and Soldón, to the south. All these rivers are tributaries of the River Sil, which runs along the west. The stratified slope deposits studied are located $950 \mathrm{~m}$ a.s.l.

Figure 4. Location of the Serra do Courel, in Galicia.

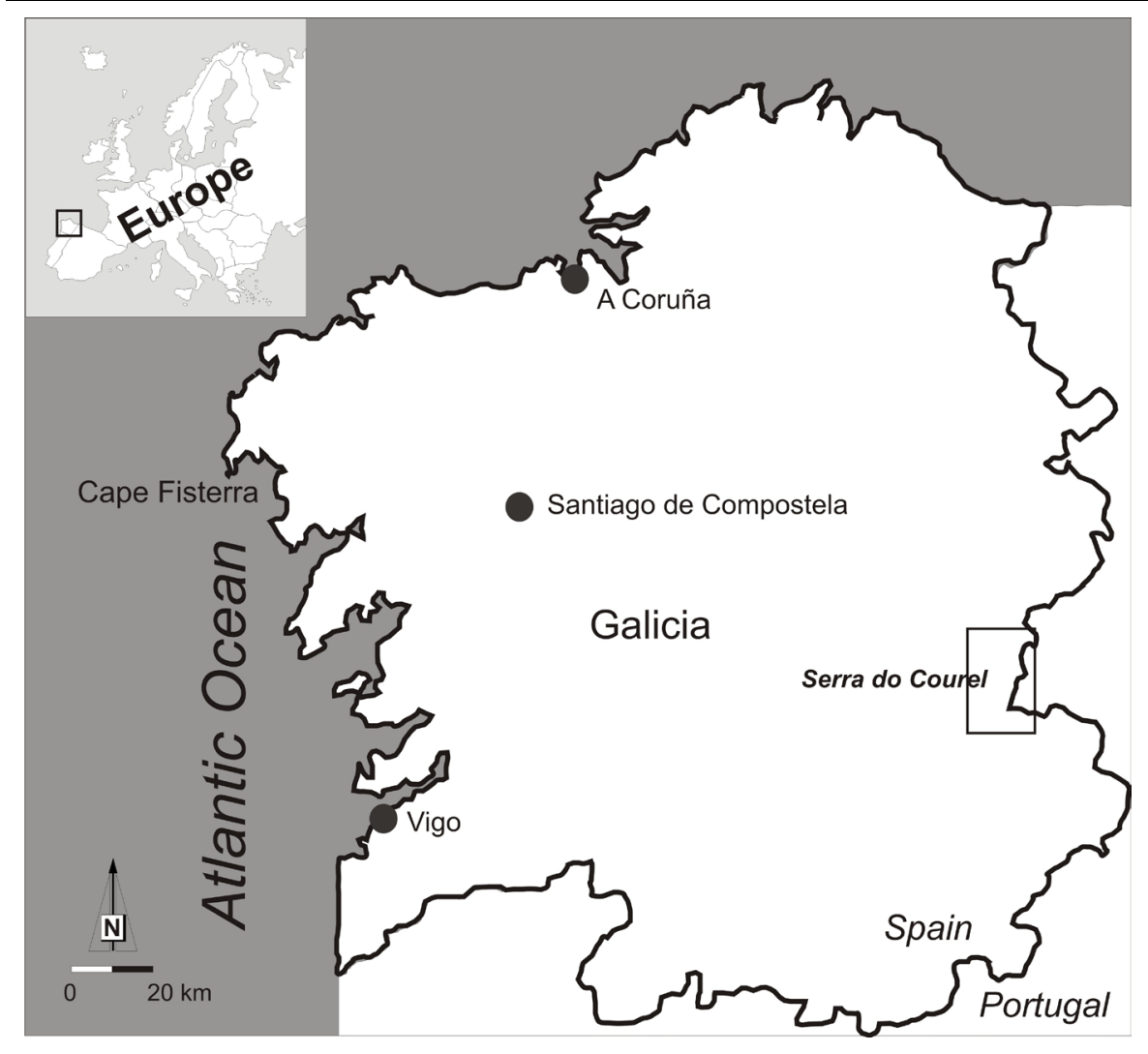

Fluvial incision associated with late Cenozoic tectonic uplift (PÉREZ ALBERTI, 1993; DE VICENTE ENTE et al., 2011) has created steep slopes (Figure 5). About $31 \%$ of the area has a gradient $>30^{\circ}, 46 \%$ between $20^{\circ}$ and $30^{\circ}$, $20 \%$ between $10^{\circ}$ and $20^{\circ}$, and only $4 \%<10^{\circ}$. In summary, in $75 \%$ of this study area the slopes have a gradient of $>20^{\circ}$. About $14 \%$ of slopes are southfacing and have a dip between $20^{\circ}$ and $30^{\circ}$, an extremely relevant fact given the importance of the slope aspect in the genesis of stratified screes. 
The area has a predominance of Cambrian to Silurian metamorphic rocks, running in parallel bands NW-SE. Slates, pelites and quartzites predominate, intercalated with some beds of limestones.

Figure 5. Topographical factors in the Serra do Courel study area: (a) slope and (b) orientation.

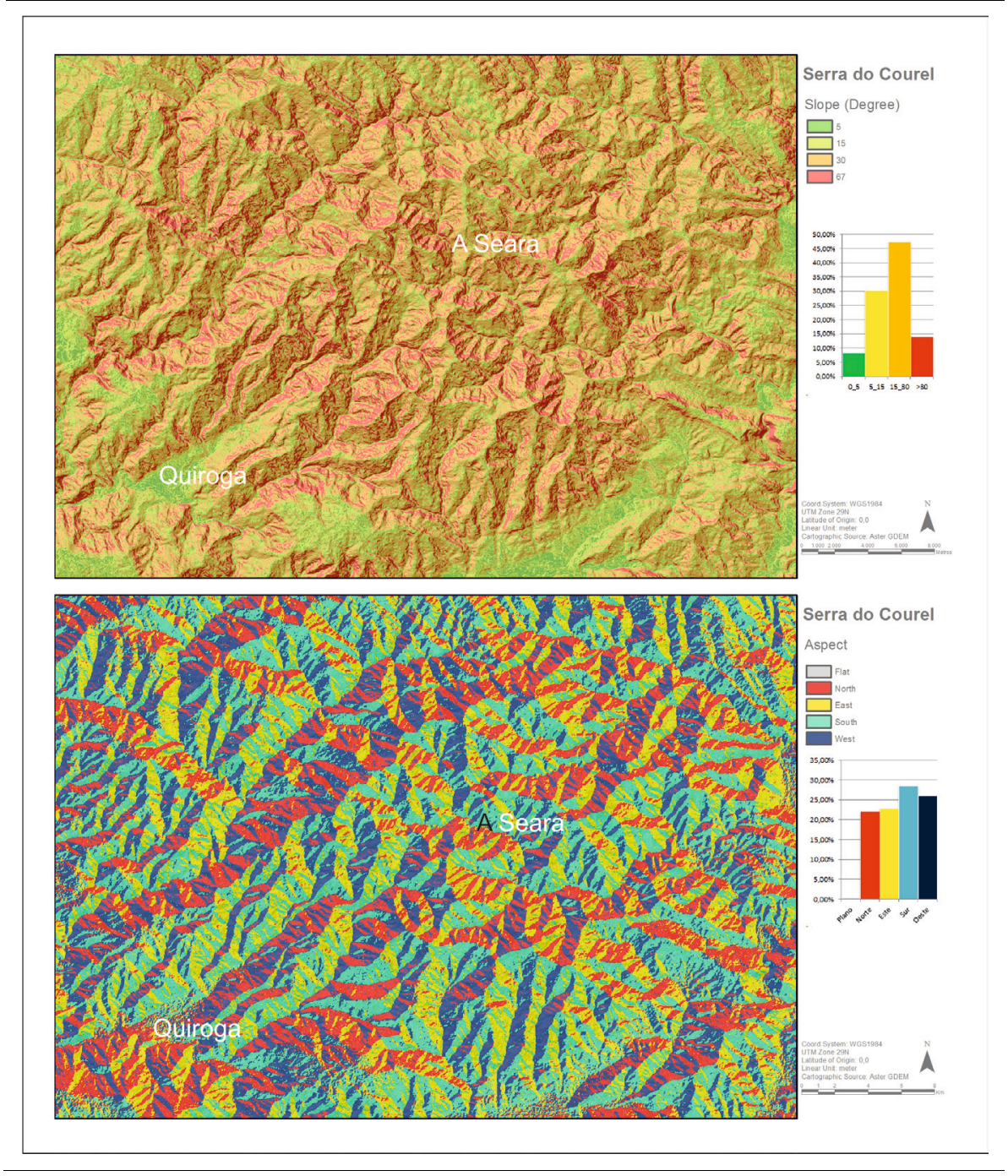

\section{III.2.b. Climate}

Nowadays,Galicia has a temperate and humid climate. $\mathrm{C}_{14}$ dating of a sample collected from a level at the base of the stratified slope deposits in the Serra 
do Courel place the coeval paleoclimate in Galicia at a date earlier than 44,000 years B.P. According to available data (PÉREZ AlBERTI et al., 2009), these deposits were coeval with cold and humid conditions during the Late Weichselian (Late Pleistocene).

\section{FIELD OBSERVATIONS AND SEDIMENTOLOGY}

\section{IV.1. Stratigraphy, lithofacies, fabric and grain size of the sedimen- tary deposits and slope dynamics in the Sierra Alvear}

In the Sierra Alvear study area, the main exposures are located in the Tristen Valley and show gravel beds with clast-supported texture, mainly consisting of pebbles, with a matrix of sand. No dating control is available, but the geomorphological characteristics allow us to conclude that the sedimentary deposits are modern. The larger clasts are usually $1-10 \mathrm{~cm}$ in size, although some clasts measuring more than $10 \mathrm{~cm}$ have been found. Blade-shaped clasts are more frequent than discoid or rod-shaped ones (FIGURE 6A). There is also an abundance of clasts that are clay-coated on their upper surface but clean underneath, especially at depths between 70 and $140 \mathrm{~cm}$.

According to the results of the grain-size analyses made, the Alvear2 site samples are dominated by pebbles (TAB. 1) but the Tristen site samples are dominated by sand (TAB. 2). In detail, at the Tristen site the matrix of the gravels consists of very coarse to medium sands, that are very poorly sorted, fine-skewed and leptokurtic (e.g., sample T5, FigURE 6B). All samples can be considered almost unimodal (with a dominant mode at 1.4 to $2.0 \mathrm{~mm}$; FIGURE 7). The curves of relative frequencies also allow us to identify a less important mode at $8 \mu \mathrm{m}$, corresponding to clay minerals. The clay fraction $(<4 \mu \mathrm{m})$ is significant $(2.8-5.9 \%)$.

$\mathrm{X}$ Ray diffraction of the $<2 \mu \mathrm{m}$ fraction in oriented samples indicate that the clay minerals present at Tristen site are illite (I), clorite (C) and kaolinite (K), in similar quantities (association ICK) (Tab. 2).

Table 1. Grain size characteristics of the Alvear 2 site samples (Sierra Alvear, Tierra de Fuego)

\begin{tabular}{lrrrr}
\hline \multicolumn{1}{c}{ Sample code } & $<63 \mathrm{um}$ & $63 \mathrm{um}-2 \mathrm{~mm}$ & $2-20 \mathrm{~mm}$ & $>20 \mathrm{~mm}$ \\
& $\%$ & $\%$ & $\%$ & $\%$ \\
\hline ZLCorr & 10,4 & 22,6 & 44 & 23 \\
L3 & 9,7 & 31,3 & 52 & 7 \\
SISE & 13,4 & 30,6 & 42 & 5 \\
SPizarras & 8,5 & 22,5 & 42 & 27 \\
SPoligono & 25,3 & 34,7 & 36 & 4 \\
\hline
\end{tabular}


Figure 6. (A) Shape of the clasts identified at Tristen Valley (Sierra Alvear), documenting the predominance of blade-shaped clasts. (B) Grain-size relative frequency curve of the matrix of sample Tristen 5, an example very similar to other samples.

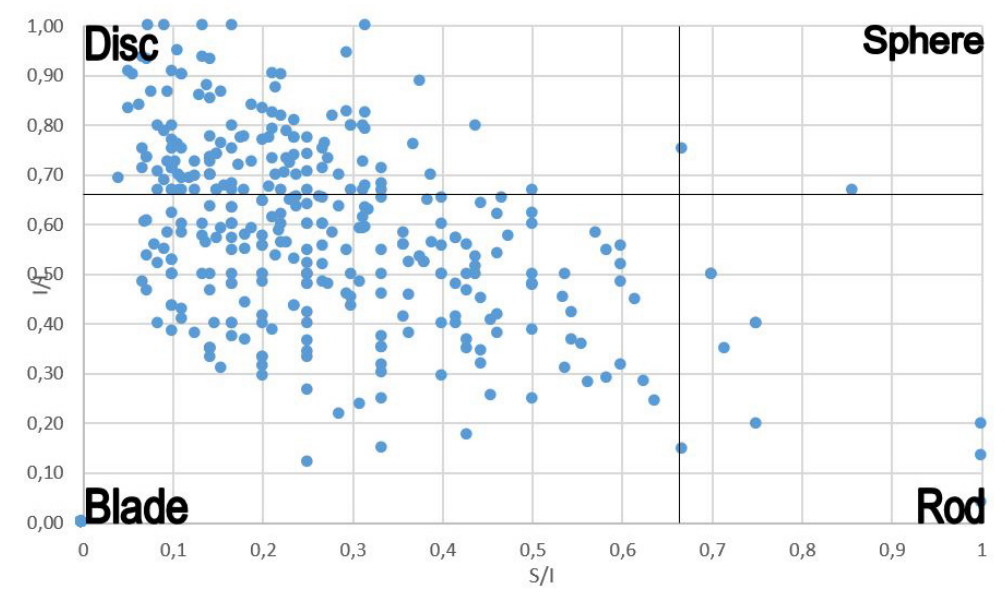

$\mathrm{A}$

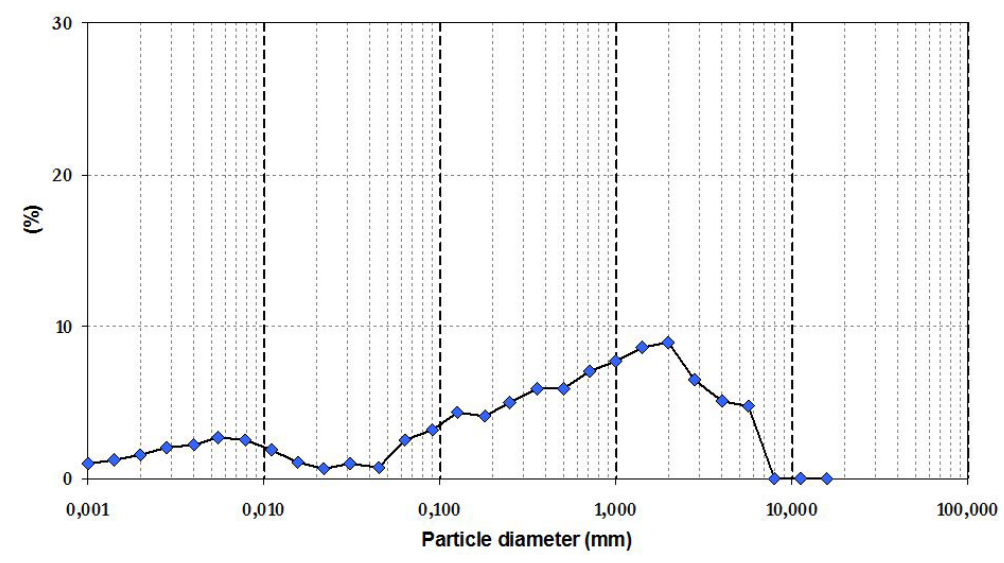

B 
Figure 7. Grain-size relative frequency curves of Tristen samples (only the $<11$ mm fraction).

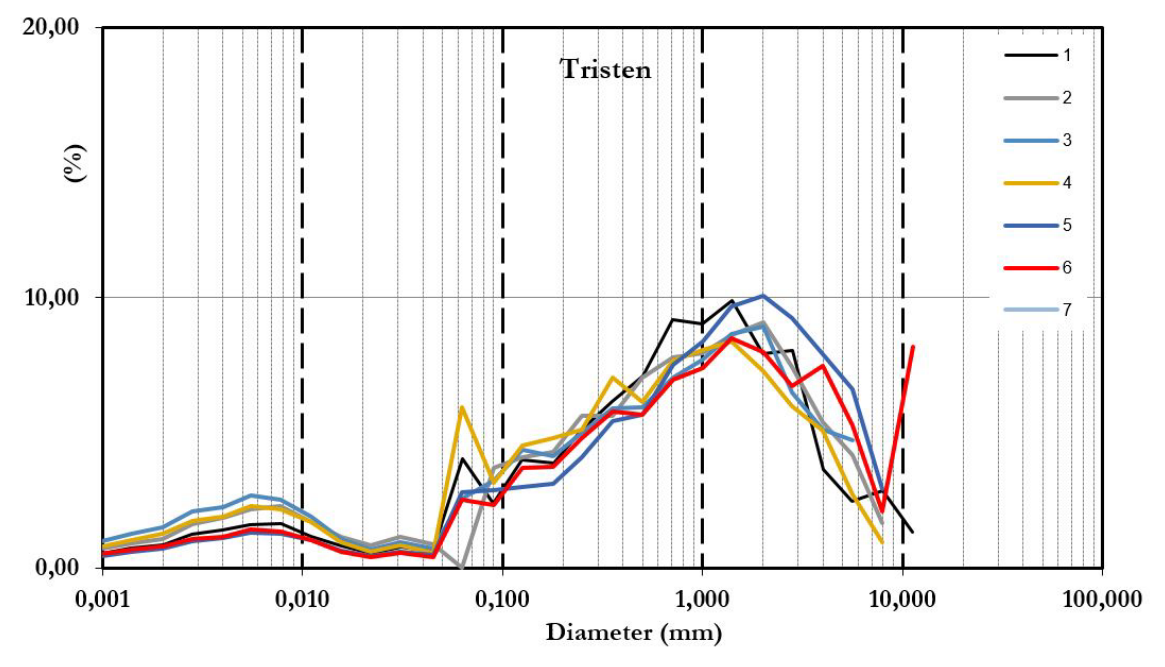

Table 2. Grain size characteristics and clay mineralogy of the samples collected from the Tristen site (Sierra Alvear, Tierra de Fuego).

\begin{tabular}{|c|c|c|c|c|c|c|c|c|c|c|c|}
\hline$A$ & $B$ & C & $D$ & $R$ & $F$ & $G$ & $H$ & $I$ & $J$ & $K$ & $L$ \\
\hline Tristen1 & 3,4 & 8,6 & 60,8 & 16,0 & 10,3 & 0,55 & 1,40 & 2,78 & 1,14 & 5,42 & ICK \\
\hline Tristen2 & 4,3 & 12,0 & 54,7 & 16,5 & 11,3 & 0,48 & 2,00 & 2,97 & 1,10 & 4,85 & ICK \\
\hline Tristen3 & 5,9 & 12,8 & 54,6 & 15,4 & 9,8 & 0,39 & 2,00 & 3,12 & 0,98 & 4,39 & ICK \\
\hline Tristen4 & 4,9 & 11,3 & 60,9 & 13,3 & 8,8 & 0,38 & 1,40 & 2,96 & 0,94 & 4,57 & ICK \\
\hline Tristen5 & 2,8 & 6,9 & 52,5 & 19,3 & 17,4 & 0,75 & 2,00 & 2,70 & 1,36 & 6,24 & ICK \\
\hline Tristen6 & 3,1 & 6,9 & 51,4 & 14,7 & 23,9 & 0,80 & 1,40 & 2,86 & 1,16 & 5,65 & ICK \\
\hline
\end{tabular}

$A$, Sample code; $B, \%$ Clay $(<4 \mu \mathrm{m}) ; C, \%$ Silt $(4-63 \mu \mathrm{m}) ; D, \%$ Sand $(63 \mu \mathrm{m}-2 \mathrm{~mm}) ;$ $E$, \% Gravel (2-4mm); F, \% Pebble (>4mm); G, Mean (mm); H, Mode (mm); $I$, Sorting; $J$, Skewness; $K$, Kurtose; $L$, Clay minerals $(<2 \mu \mathrm{m})$

The predominance of blade-shaped clasts, that are usually $1-10 \mathrm{~cm}$ in size, could result from the genesis of clasts by gelifraction. The fact that the sediment samples are fine-skewed and very poorly sorted can be interpreted as a result of very short transport and a limited evacuation of fines. The presence of a clay fraction in the sediment samples and in the incipient soil that covers the geological substratum is consistent with a temperate-cold and humid climate that could produce kaolinite by chemical weathering, chlorite and illite being the detritical clay minerals provided by erosion of the geological substratum (basalts and slates).

Most of the clasts are oriented parallel to the slope direction (FIGURE 8) but also, to a great extent, with their longest axis perpendicular to it. Nevertheless, 
there is a clear dispersion, particularly at places where the slope has a dip of $20^{\circ}$ to $30^{\circ}$. On the other hand, when the gradient is less than $15^{\circ}$, the data display more regularity. In summary, the observations on the trenches revealed that upslope lithofacies mainly correspond to alternating clast-supported coarse- and fine-grained layers, whereas predominantly gravelly and pebbly layers occur downslope from the top to the bottom of the studied slope. There istherefore a progression from an upper sector displaying an alternation of beds comprising gravels and sands, to a middle one in which stratified gravels predominate, to debris flow lobes covering the whole slope at the bottom. Fabric analysis reveals that, with an increase in gradient, the dispersion in the orientation of the clast axis increases.

In the study area, the slate bedrock has a $55^{\circ} \mathrm{W}$ dip. Adjacent to a bedrock outcrop, the sedimentary cover has the following characteristics: heterometric massive clast-supported texture predominating on the higher slopes, with the greatest dip $\left(>30^{\circ}\right)$; an alternation of stratified coarse and fine clasts on the middle slopes, with a smaller dip $\left(15^{\circ}-20^{\circ}\right)$; and clast-supported accumulations once again predominating in the debris flow lobes $\left(>30^{\circ}\right)$.

Detailed examination reveals the several ways in which the clasts could be mobilised (FIGURE 9). These are summarised as follows.

— Melt channels (FIGURE 9A). These are seen on the southern slopes, at places where there is a change in slope gradient. They have a smooth surface and are floored by a mixture of clasts and mud.

- Surface clast flows (FIGURES 9B and 9C). These have accumulations of clasts parallel or perpendicular to the slope and imbrications of pebbles. The former tend to fossilise sectors of fines with circular fragmentation, while the latter are associated with the same fracturing, but in a vertical direction. In this case, the desiccation cracks control the movement of clasts, which accumulate in the small hollows.

- Small mud flows (FIGURE 9D). These are found at the edges of snowpatches. The abundance of silt and water would have provoked flows as a result of excessive hydrostatic loading.

- Sandy rills (FIGURES 9E and 9F). These are associated with snowpatches and are characterised by having a small central channel ending in a fan geometry.

- Stone-banked solifluction lobes (FIGURES 9G and 9H). These have a planar arrangement and show adepositional sequence consisting of successive layers of clasts. 
Figure 8. Fabric and orientation of clasts in the study area located at Tierra del Fuego.

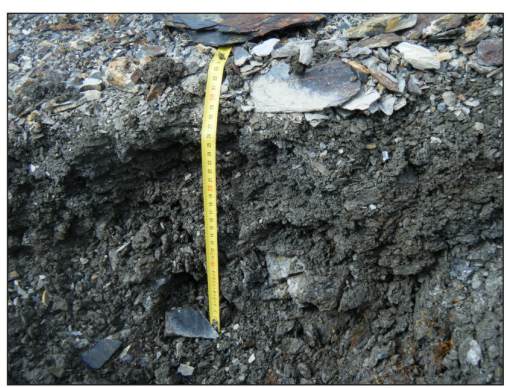

A
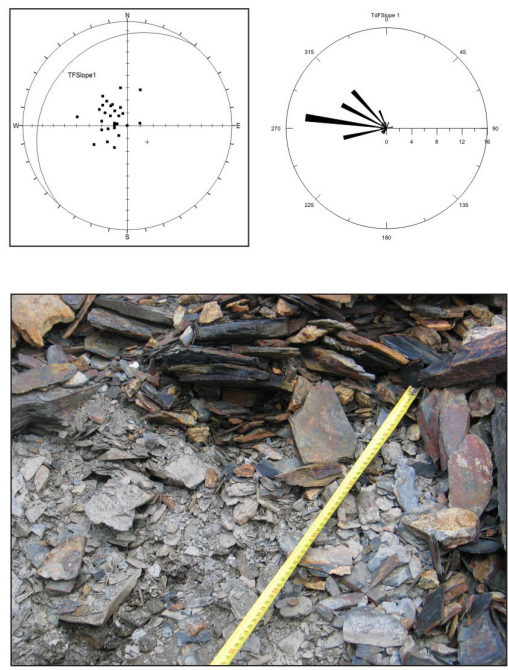

C
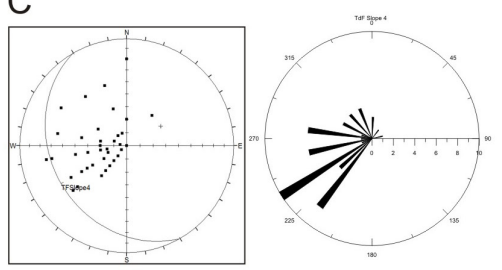

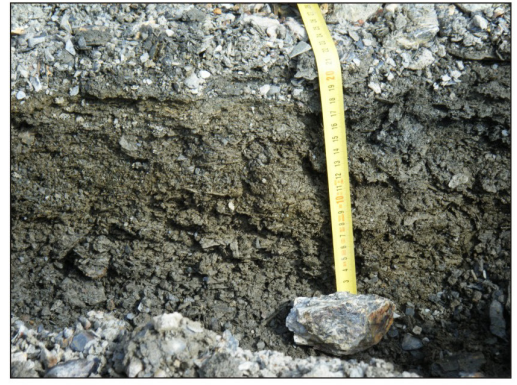

B
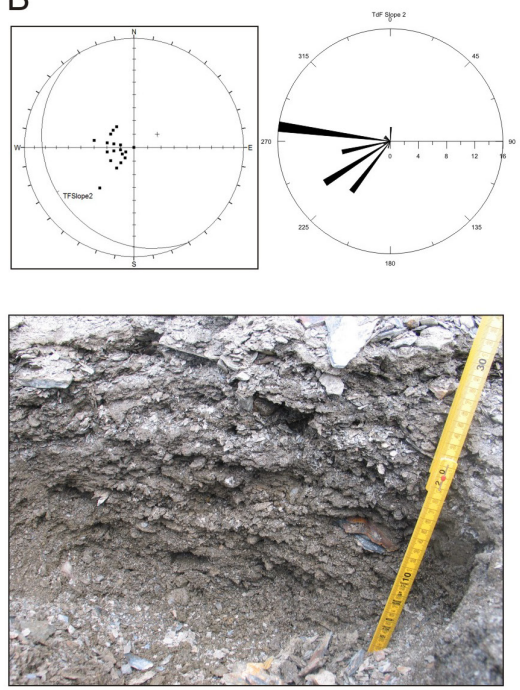

$\mathrm{D}$
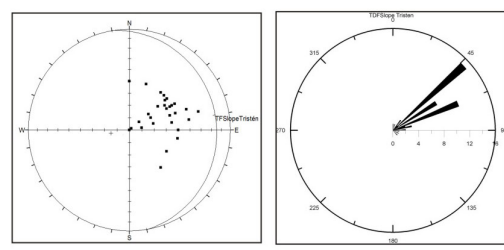
Figure 9. Types of depositional facies and interpreted transport processes in the Tierra del Fuego study area. A - Melt channels; B and C - Surface clast flows; D Small mudflows; $E$ and $F$ - Small sand flows; $G$ and $H$ - Mantle flows of clasts.
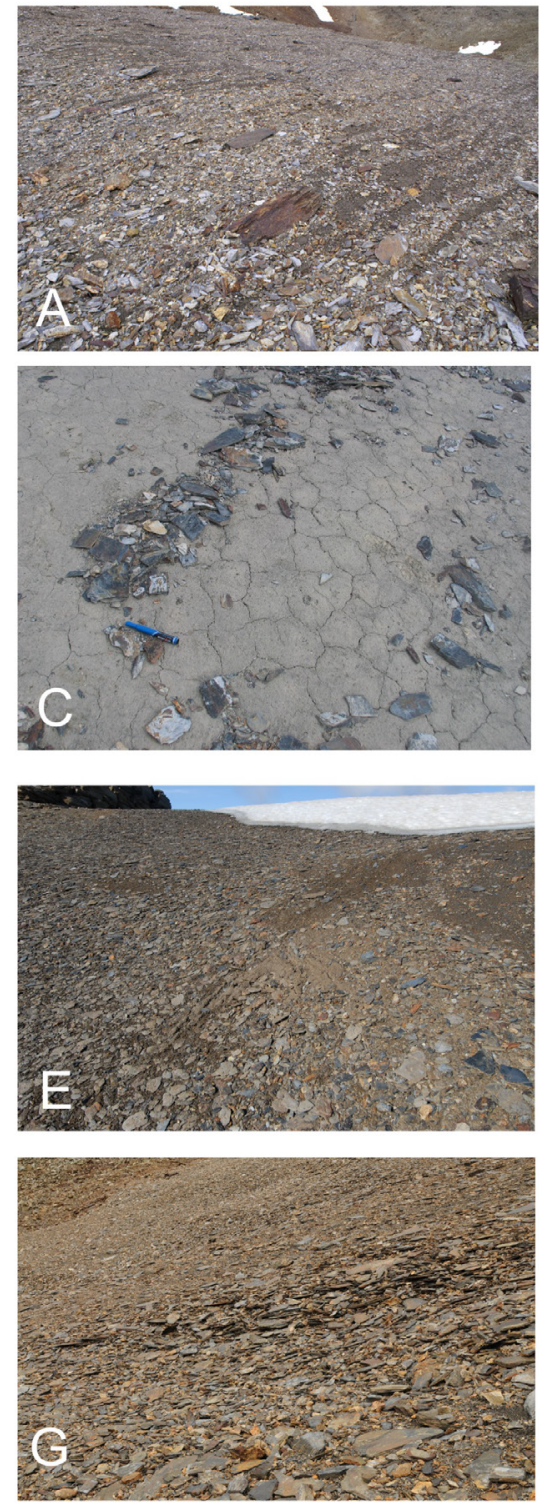
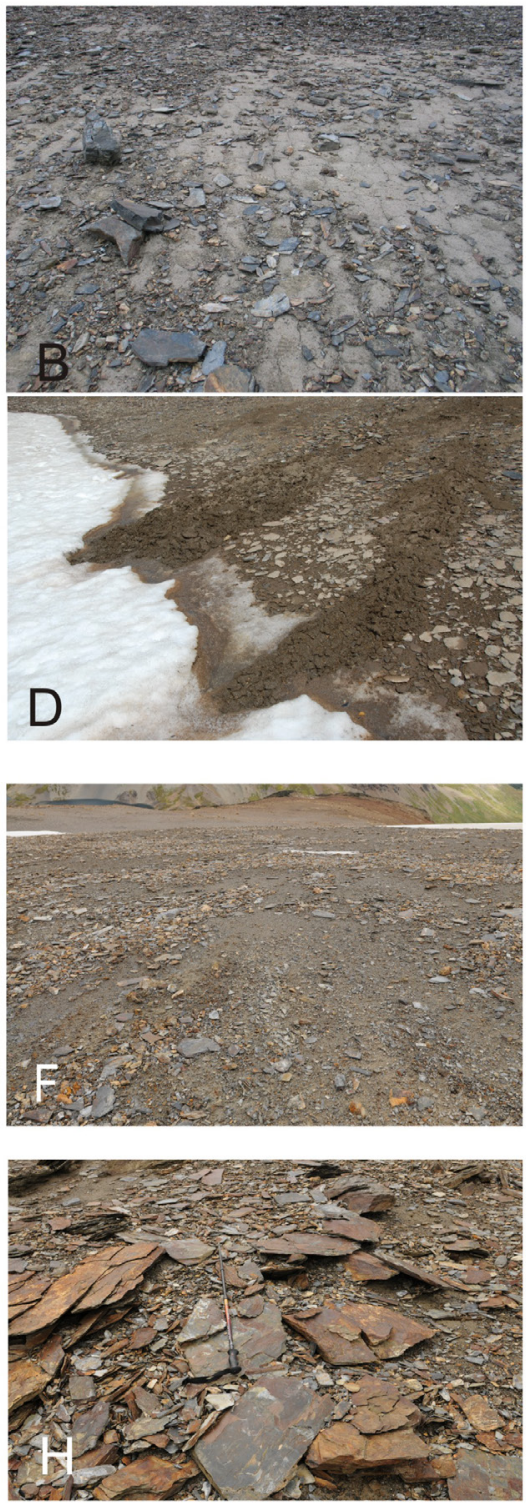


\section{IV.2. Stratigraphy, lithofacies, fabric and grain size of the sedimen- tary deposits in the Serra do Courel}

The present-day slope processes in the Serra do Courel study area are hampered by the dense vegetation cover. Outcropsshow a stratigraphy of gravel beds with clast-supported texture, mainly consisting of pebbles with a sand matrix. The sediment usually consists of two sub-populations: (i) medium pebbles to small cobbles (usually $1-10 \mathrm{~cm}$, although clasts $>10 \mathrm{~cm}$ have also been found) predominate over (ii) a matrix of fine pebbles to sand.

Blade-shaped clasts predominate but disc-shaped ones are also frequent (FIGURE 9A). Some vertical clasts would seem to have been expelled by frost activity. There is an abundance of clasts that are coated by fines (silt to clay) on their upper surface but clean underneath.

According to the results of the grain-size analyses made to the fraction $<11 \mathrm{~mm}$ of the sediment samples collected from the Seara 2 site (TABLE 3), the matrix of the gravels is very poorly sorted, very fine to fine skewed and platykurtic to very platykurtic(e.g., sample Seara 4, FIGURE 10B). All samples can be considered almost unimodal (a dominant mode at 2 to $11 \mathrm{~mm}$; FIGURE 11). The curves of relative frequenciesalso allow us to identify a less important mode at $10 \mu \mathrm{m}$, corresponding to clay-minerals. X Ray diffraction provided the information that the clay minerals present in the $<2 \mu \mathrm{m}$ fraction of the sediment samples comprise illite (dominant), clorite and kaolinite (association Ick). The predominance of illite indicates that weathering physical processes are more relevant than chemical processes. Clorite and illite are directly sourced (detritical) by the basement rocks. The presence of kaolinite indicates the existence of periods with some humidity, allowing the hydrolysis of silicates to some extent.

Table 3. Grain size characteristics and clay mineralogy of the sediment samples (<11 mm fraction) collected from the Seara 2 site (Serra del Courel, Galicia).

\begin{tabular}{crrrrrrrrrrr}
\multicolumn{1}{c}{$A$} & $B$ & $C$ & $D$ & $R$ & $F$ & $G$ & $H$ & $I$ & $J$ & $K$ \\
\hline Seara 2.1 & 4,6 & 17,4 & 33,6 & 12,69 & 30,15 & 0,60 & 5,61 & 3,51 & 0,84 & 3,63 & Ick \\
Seara 2.2 & 1,4 & 6,0 & 16,3 & 12,2 & 63,61 & 2,47 & 11,20 & 2,65 & 2,08 & 9,06 & Ick \\
Seara 2.3 & 2,2 & 77 & 27,8 & 21,6 & 40,2 & 1,42 & 4,00 & 2,83 & 1,64 & 7,14 & Ick \\
Seara 2.4 & 1,7 & 7,31 & 24,4 & 18,5 & 47,3 & 1,65 & 5,61 & 2,74 & 1,73 & 7,27 & Ick \\
Seara 2.5 & 2,2 & 7,6 & 32,9 & 21,0 & 35,5 & 1,23 & 4,00 & 2,81 & 1,49 & 6,74 & Ick \\
Seara 2.6 & 1,0 & 3,2 & 4,1 & 10,2 & 81,3 & 3,88 & 5,61 & 2,01 & 3,61 & 22,6 & Ick \\
Seara 2.7 & 3,2 & 12,5 & 38,1 & 19,8 & 25,6 & 0,75 & 2,80 & 3,12 & 1,10 & 4,40 & Ick \\
Seara 2.8 & 2,3 & 7,9 & 12,7 & 8,2 & 68,3 & 2,29 & 7,92 & 2,90 & 2,05 & 8,70 & Ick \\
Seara 2.9 & 4,0 & 14,7 & 41,1 & 17,7 & 21,5 & 0,57 & 2,00 & 3,23 & 0,96 & 3,89 & Ick \\
Seara 2.10 & 1,9 & 6,1 & 11,1 & 7,2 & 72,7 & 2,88 & 11,20 & 2,74 & 2,27 & 10,35 & Ick
\end{tabular}

$A$, Sample code; $B, \%$ Clay $(<4 \mu \mathrm{m}) ; C, \%$ Silt $(4-63 \mu \mathrm{m}) ; D, \%$ Sand $(63 \mu \mathrm{m}-2 \mathrm{~mm}) ;$ $E$, \% Gravel (2-4mm); $F, \%$ Pebble ( $>4 \mathrm{~mm}) ; G$, Mean (mm); $H$, Mode (mm); $I$, Sorting; $J$, Skewness; $K$, Kurtose; $L$, Clay minerals $(<2 \mu \mathrm{m})$ 
The sediment samples collected from the Toca site (TABLE 4) are dominated by sand and silt fractions, and the clay fraction is more relevant (4.2-12.6\%); they are also very poorly sorted, symmetrical, mainly platykurtic and bimodal (0.01-11.2 mm; FIGURE 12). The clay mineral association is dominated by Vermiculite (usually Vik), pointing to a higher chemical weathering.

Table 4. Grain size characteristics of the sediment samples (<11mm fraction) collected from the Toca site (Serra del Courel, Galicia).

\begin{tabular}{ccccccccccccc}
$A$ & \multicolumn{1}{c}{$\boldsymbol{B}$} & $C$ & $D$ & $R$ & $F$ & $G$ & $H$ & $I$ & $J$ & $K$ \\
\hline Toca 1 & 11,2 & 36,0 & 29,3 & 10,7 & 9,7 & 0,10 & 0,01 & 3,70 & $-0,06$ & 2,20 \\
Toca 2 & 11,7 & 37,5 & 33,4 & 8,1 & 6,1 & 0,09 & 0,01 & 3,51 & $-0,09$ & 2,42 & Vik \\
Toca 3 & 12,6 & 40,1 & 20,8 & 5,7 & 15,4 & 0,09 & 0,01 & 3,96 & $-0,26$ & 2,14 & Vik \\
Toca 4 & 7,1 & 29,0 & 30,1 & 12,8 & 19,2 & 0,24 & 5,61 & 3,81 & 0,36 & 2,18 & IKv \\
Toca 5 & 4,2 & 21,9 & 20,6 & 9,4 & 43,2 & 0,66 & 11,20 & 3,94 & 0,75 & 2,46 & Vik \\
Toca 6 & 5,5 & 30,6 & 45,7 & 9,5 & 7,63 & 0,18 & 1,00 & 3,40 & 0,24 & 2,22 & Vik \\
Toca 7 & 4,4 & 19,3 & 34,1 & 14,5 & 27,0 & 0,50 & 7,92 & 3,65 & 0,73 & 2,66 & Vik \\
Toca 8 & 5,2 & 19,7 & 32,7 & 12,8 & 25,3 & 0,43 & 7,92 & 3,71 & 0,67 & 2,61 & Vik \\
Toca 9 & 4,2 & 20,0 & 25,1 & 10,4 & 28,1 & 0,49 & 5,61 & 3,58 & 0,77 & 2,79 & Vik \\
Toca 10 & 5,4 & 28,3 & 31,4 & 11,3 & 22,6 & 0,28 & 4,00 & 3,84 & 0,31 & 2,04 & Vik \\
Toca 12 & 4,7 & 26,8 & 34,6 & 11,4 & 21,5 & 0,30 & 4,00 & 3,69 & 0,38 & 2,21 & Vik \\
Toca 13 & 2,7 & 10,6 & 24,9 & 14,6 & 44,5 & 1,24 & 5,61 & 3,22 & 1,44 & 5,07 & Vik \\
Toca 14 & 5,5 & 22,4 & 40,0 & 12,0 & 18,9 & 0,33 & 2,00 & 3,61 & 0,51 & 2,55 & Vik
\end{tabular}

$A$, Sample code; $B, \%$ Clay $(<4 \mu \mathrm{m}) ; C, \%$ Silt $(4-63 \mu \mathrm{m}) ; D, \%$ Sand $(63 \mu \mathrm{m}-2 \mathrm{~mm})$; $E$, \% Gravel (2-4mm); F, \% Pebble ( $>4 \mathrm{~mm}) ; G$, Mean (mm); $H$, Mode (mm); , Sorting; $J$, Skewness; $K$, Kurtose; $L$, Clay minerals $(<2 \mu \mathrm{m})$

Figure 10. (A) Shape of theclasts identified at the A Seara outcrop, documenting the predominance of blade-shaped clasts. (B) Grain-size relative frequency curve of the matrix of sample A Seara 2.4, an example very similar to other samples.

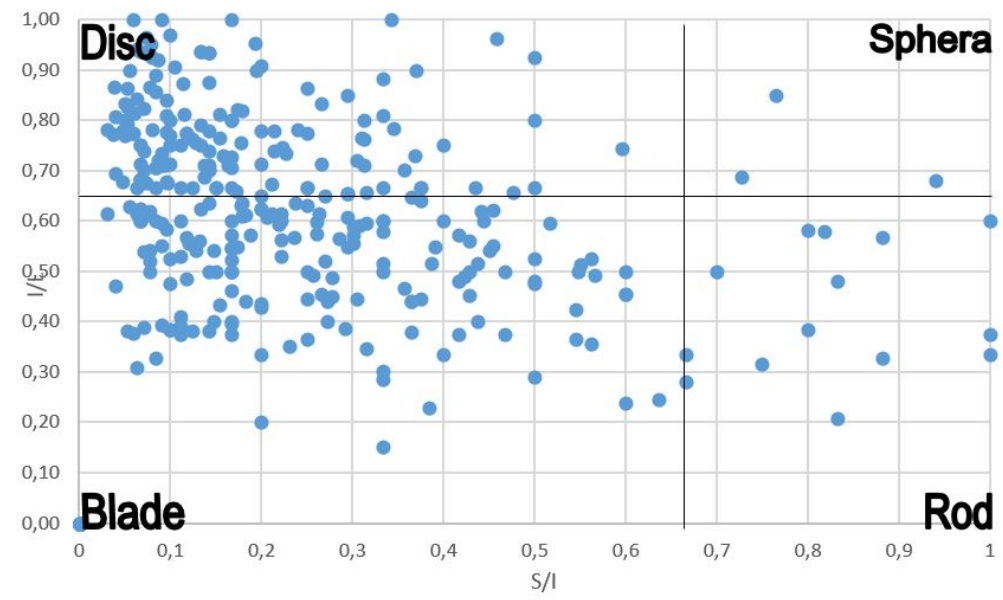




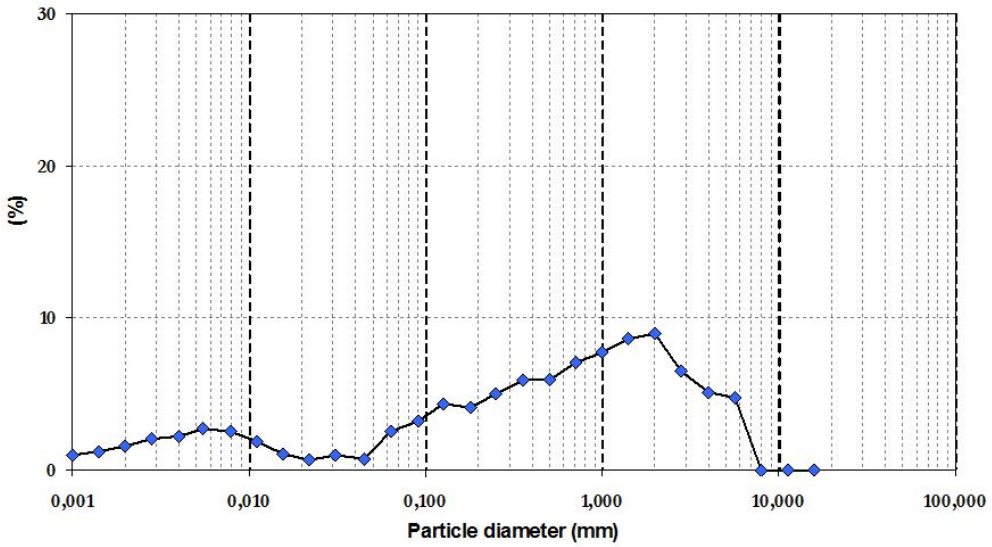

B

In all the studied sites, fabric analyses indicate a clear orientation of the clasts as being longest axis parallel to the slope dip but also some relevance of orientation perpendicular to this (Figure13).

Figure 11. Grain-size relative frequency curves of Seara 2 samples (only the $<11$ mm fraction).

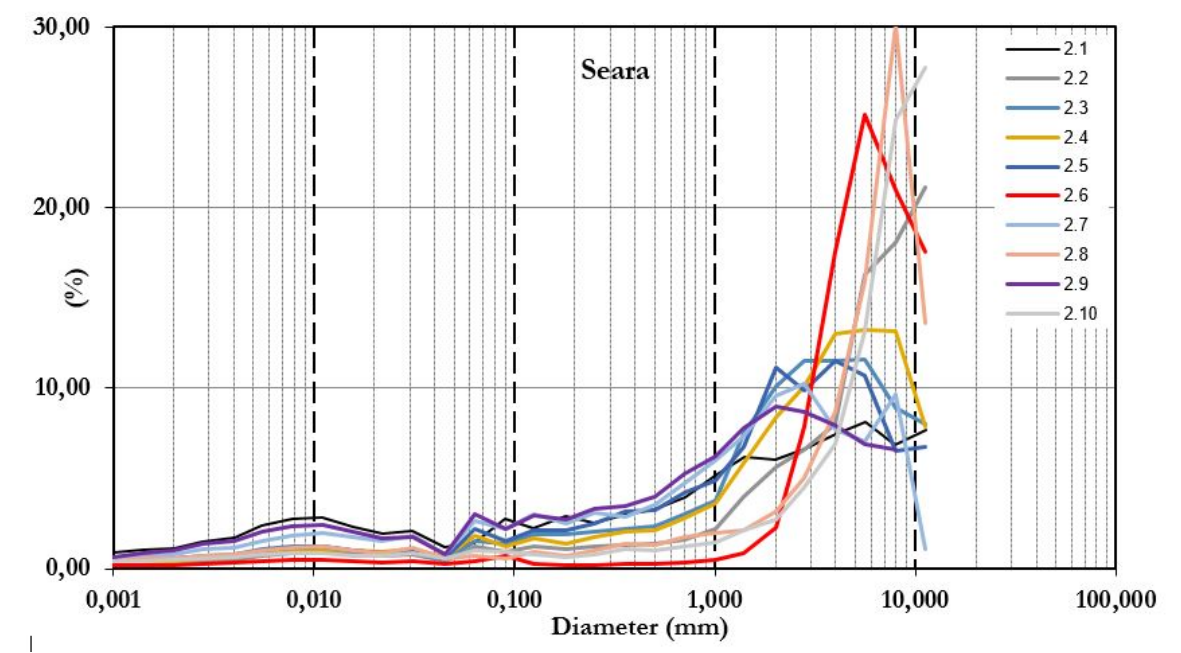


Figure 12. Grain-size relative frequency curves of Toca samples (only the $<11 \mathrm{~mm}$ fraction).

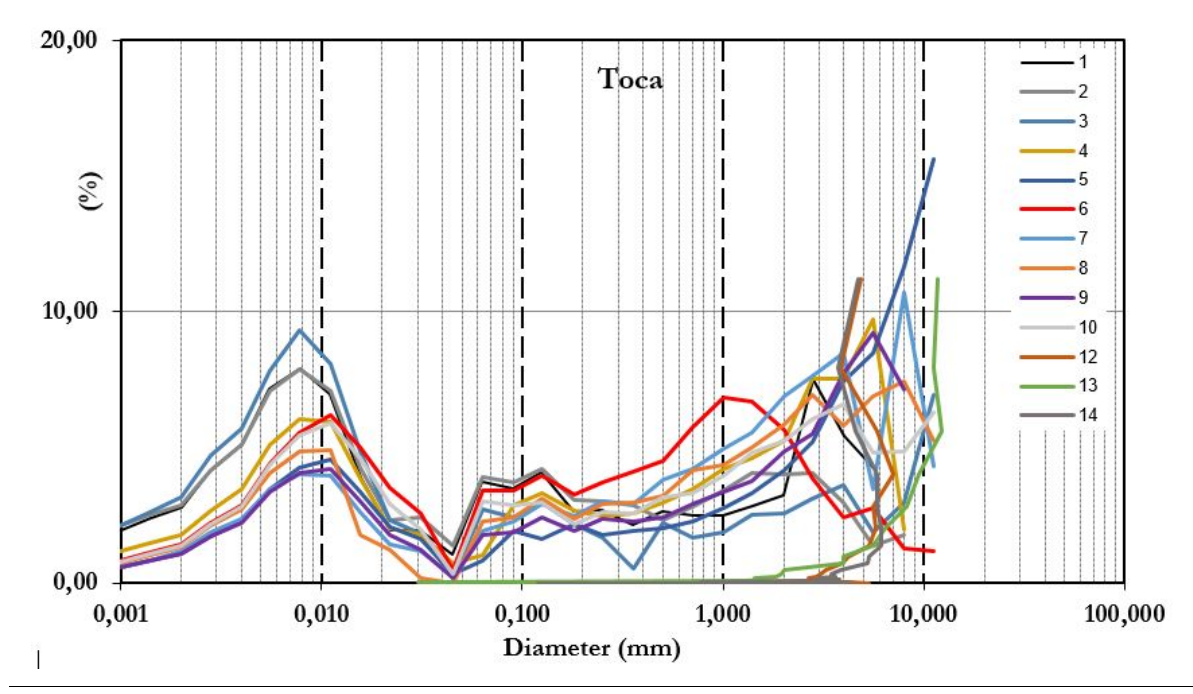

\section{DISCUSSION}

This section focuses on the relevance and validity of using Tierra del Fuego as a modern analogue for the conditions involved in the development of stratified slope deposits in ancient Galicia. The current climatic conditions and associated sedimentary processes and facies, described earlier for Tierra del Fuego, are therefore briefly summarised here and used to infer the Late Pleistocene environmental and sedimentary processes coeval with the formation of similar deposits of Galicia.

\section{V.1. Slope dynamics in Tierra del Fuego}

In Tierra del Fuego, large accumulations of stratified slope deposits are observed in places where the mean annual temperature does not rise above $-2^{\circ} \mathrm{C}$, with a high degree of variability in spring, summer and autumn and much greater stability in winter. REDONDO VEGA (2004) inferred the probable presence of permafrost in these mountain areas due to the identification of an active rocky glacier at Hill Krund. The existence of permafrost at high elevations and the fact that a large number of freeze-thaw cycles do not only produce coarse clasts but also fine particles, has been demonstrated (VALCÁRCEL et al., 2006; PÉREZ AlBERTI, 2008). More recently, SANTOS GONZÁleZ et al. (2015) also used temperature records to confirm the existence of permafrost in the same area. 
Figure 13. Facies (A) and fabric (B) of the sedimentary deposits at the Seara 2 outcrop.
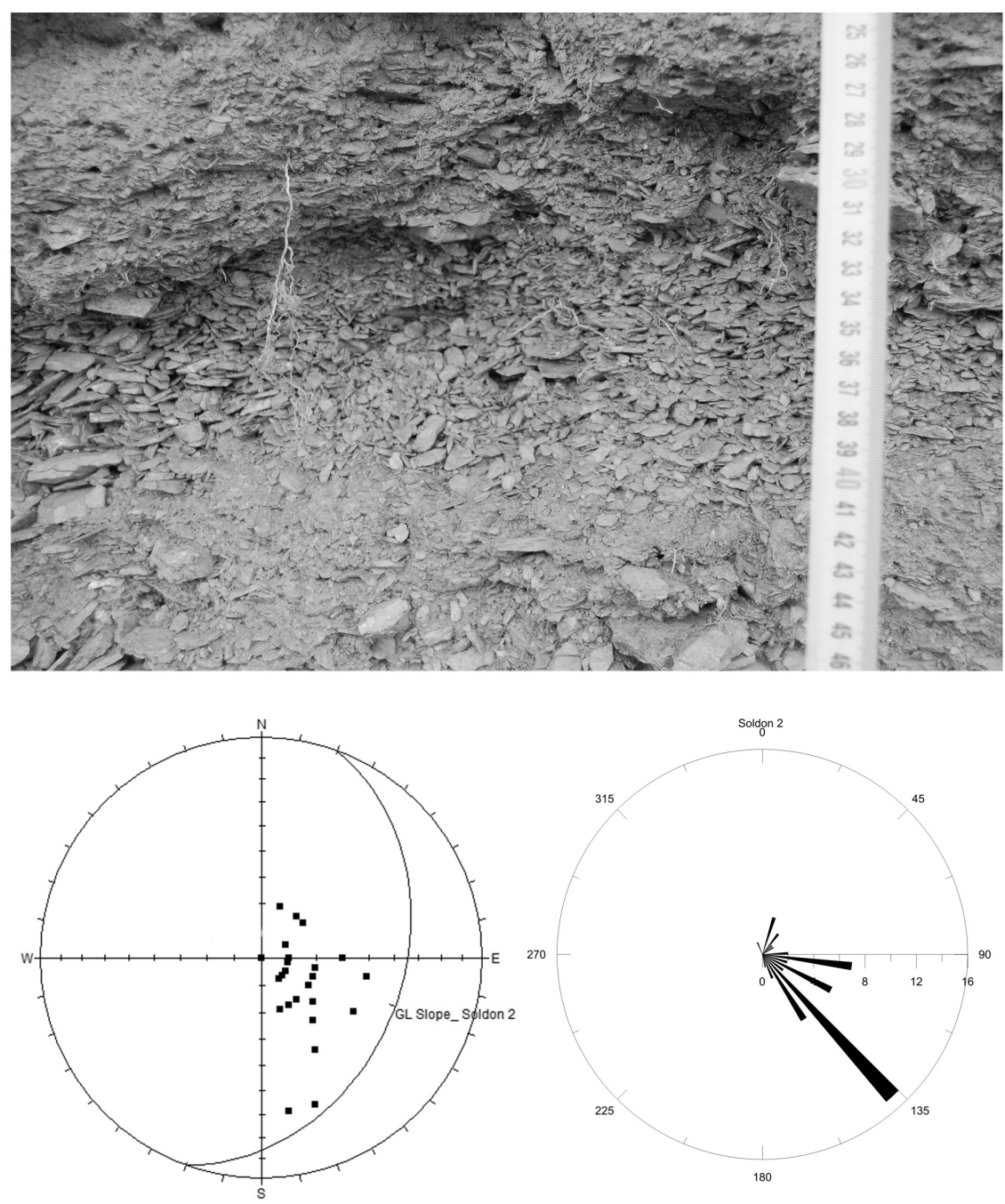

The expulsion of stakes (PÉREZ ALBERTI, 2008) indicates frost heave, although with no marked discrimination between fine and coarse sediment. This is related to the continuous processes of slope movement and accretion. There is a constant provision of sediments that are in continuous movement along the slope; sub-surface clasts, even though they move vertically, remain buried because they do not have sufficient time to emerge at the surface. It has also 
been demonstrated that stakes partially expelled in one year were buried during the following year. This indicates that variations in sediment sequences are controlled more by the quantity of materials in movement on the slope than by vertical selection processes.

The coexistence of gravels with a sandy matrix indicates intense fragmentation of source rocks, followed by short transport. The presence of some clay fraction is explained by moderate hydrolysis, producing some clay minerals. The high degree of correlation between clast dip and clast longest axis orientation (parallel or perpendicular) in relation to slope, together with the existence of a continuous mantle of heterometric sediments throughout the slope, indicates a dual mobilisation: (i) slow transport over a short distance, associated with rise and fall due to frost creep; and (ii) fast transport but over an equally short distance, due to snow melt, taking the form of small streams, debris flows or mudflows.

The stratified slope deposits in Tierra del Fuego are the result of interrelated processes in a cold maritime environment in which water availability and temperature variability are major controls. These circumstances lead to major changes in the snow mantle, which remains stable in winter and becomes unstable in spring and autumn.

Melt water would be the cause of mudflows and small debris flows. The lifting of the surface layer of the ground and the formation of pipkrakes associated with continuous freeze-thaw changes during spring and autumn would favour clast creep. All this would explain the discontinuities that can be seen at the surface, with the presence of sites in which fines (silt and clay) are buried by accumulations dominated by large pebbles next to others presenting smaller pebbles and with a matrix of fines. Stone banked lobes only appear on slopes with a dip of more than $30^{\circ}$ and with major lateral contributions of clasts, which prograde towards the lower part of the slopes. Their location in a corridor where snow collects in winter but does not last long brings to mind the possibility of solifluction.

Another point to note is the high degree of lithological control in the genesis of the stratified screes, because these were only found on areas consisting of foliated rocks, which also presented stratification and intense fracturing. On slopes with the same dip, the transition from a substratum of slates to volcanic rocks leads to a transition from stratified gravel screes to heterometric pebble to boulder coarser accumulations. Thus, topography and lithology both play a decisive role in the genesis of this type of stratified deposits. 


\section{V.2. Contribution of the data from Galicia in relation to those from Tierra del Fuego}

The characteristics of the Late Pleistocene sedimentary deposits studied in the Serra do Courel (Galicia) (GUITIÁN RIVERA y PÉREZ ALBERTI, 1992; PÉREZ ALBERTI et al., 2009) corroborate the hypothesis that lithology is a first order factor in the genesis of stratified screes on slopes. As documented by the similar modern deposits studied at Tierra del Fuego, stratified screes only appear on slopes with a substratum of slates, similar foliated pelitic rocks, or other rocks that mainly produce blade clasts. Another common characteristic with Tierra del Fuego is a clear alternation of layers and a diffuse relationship between these, geometrically characterised by the existence of tongues that are imbricated amongst themselves.

At Serra do Courel, as at Tierra del Fuego, there is a marked relationship between slope dip and the direction of the clasts' longest axis. There is another element that may well be significant: both outcrops document vertical clasts that appear to have been expelled as a result of frost activity. Although at Tierra del Fuego a lamina of clay was observed on top of the clasts, as is also the case in Galicia, and frost-heave processes were also apparent, in the outcrops studied there were no such traces deep down. However, this fact has to be treated with extreme caution since the exposures observed are quite different: in Galicia they were large while in the Fuegian Andes they were much smaller.

\section{CONCLUSIONS}

Tierra del Fuego and Galicia are two regions suitable for a comparative geomorphological study because Tierra del Fuego can reasonably be viewed as being a modern analogue for the cold and humid climate conditions that must have existed in Galicia during the Late Pleistocene.

In both areas, the lithological and structural characteristics of the source rocks play a major role in clast genesis. Slates are the type of rock most affected by frost-action processes, due to their high degree of tectonic fragmentation, together with their strong foliation. To this we must add the rate of chemical weathering, which seems to be greater in Galicia than in Tierra del Fuego, expressed by a more significant quantity of clay fraction.

Topographical factors, such as slope dip and exposure, are of relevance in explaining differences in the depositional sequences. When the slope dip exceeds $30^{\circ}$, gravity plays a decisive role in the type of accumulations. In the case of Tierra del Fuego, when the dip is $30-35^{\circ}$, there is a predominance of stone-banked lobe deposits; when it exceeds $35^{\circ}$, there is a predominance of 
scree slopes and debris flow deposits. The presence of debris flows is dependent on the existence of a site where snow can accumulate.

Climatic factors, in the form of temperature variability at both air and ground levels, are also fundamental. The increase in freeze-thaw cycles in spring and autumn not only produces changes in the state of water, with the subsequent generation of surface frost-heave processes, but also run-off water which, according to whether melt speed is high or low, generates either surface sand or pebble flows. Mudflows occur when slow melt speeds lead to an excessive hydrostatic load and resulting flow. Changes at surface level, which are numerous, favour frost creep and the parallel mobilisation of clasts. This leads to different types of transport on the slope, these being conditioned by perpendicular and lateral clast contributions. In the case of Tierra del Fuego, these are abundant, favouring the continuous feeding of the slope and their subsequent accretion.

These factors promote an active process of frost-heave on the slopes, which is visible on flat surfaces, but not with all kinds of lithologies. On silty-sand soils, such as those that have developed on volcanic rocks, stakes are actively jacked. However, the response is totally different on slaty materials.

There is a high degree of similarity between the stratified slope deposits studied in Tierra del Fuego and Galicia. They are both accumulations that were generated in a cold and humid climate, which accounts for the mobility of materials on the slopes and for a significant degree of chemical weathering. $\mathrm{A} \mathrm{C}_{14}$ age collected from sample a level at the base of the studied deposits in the Serra do Courel places this climate in Galicia to a date earlier than 44,000 years B.P.

\section{ACKNOWLEDGEMENTS}

We are grateful to Rodolfo and Rodrigo Iturraspe for their assistance in the field, and to the Laboratory of Sedimentology of the Dep. Earth Sciences Univ. Coimbra for the grain-size analysis and identification of clay minerals. The research at Tierra del Fuego was carried out within the framework of projects CGL2004-03380/BOS and POL2006-PC091 conducted by the Spanish Ministry of Education and Science. This study was also supported by the Fundação para a Ciência e a Tecnologia, through project UID/MAR/04292/2013 - MARE.

\section{REFERENCES}

BertRAN, P. y TEXIER, J.P. (1999): «Facies and microfacies of slope deposits». Catena, 35 (2/4), 99-121. 
Bertran, P. ; Coutard, J.P. ; Francou, B.; Ozouf, J.-C. y Texier, J.P. (1992): «Données nouvelles sur l'origene du lintage des grèzes: implications paléoclimatiques». Geographie Phisique et Quaternaire, 46 (1), 97-112.

Bertran, P. ; COUTARD, J.-P. ; OzOUf, J.-C. y TEXIER, J.-P. (1995): «Dépôts de pentecalcaires du nord de l'Aquitanie. Répartition stratigraphique et géographique des faciès».Zeitschriftfür Geomorphologie, 39 (1), 29-54.

Bertran, P.; Texier, J.P. ; Coutard, J.-P. ; Ozouf, J.C. y Francou, B. (1994): «Contribution au débat sur l'orige du litage des grèzes». Quaternaire, 5 (1), 41 46.

CailleuX, A. (1948): Études de cryopedologie. Centre de Documentation Universitaire (CDU), Paris, $68 \mathrm{p}$.

DE BLASIO, F.V. y SÆTER, M.B. (2009): «Small-scale experimental simulation of talus evolution». Earth Surface Processes and Landforms, 34 (12), 1685-1692.

De Vicente, G.; Cloetingh, S.A.P.L.; VAn WeEs, J.D. y CunHA, P.P. (2011): «Tectonic classification of Cenozoic Iberian foreland basins». Tectonophysics, 502 (1), $38-61$.

DeWolf, Y. (1987): «Dépôts de pente stratifiés». Notes et comtes-rendus du groupe de travail: Régionalisation du Périglaciaire, Comité National Français de Géographie, XI-XII, 19-39.

DYLIK, J. (1967): «Solifluxion, congelifluxion and related slope processes». Geografiska Annaler, 49 (2/4), 167-177.

FRANCOU, B. (1989): «La stratogénèse dans les formations de pente soumisses à l'action du gel. Une nouvelle conception du problème». Bulletin de l'Association Française por l'Étude du Quaternaire, 26 (4), 185-199.

FRANCOU, B. (1990): «Stratification mechanisms in slope deposits in high subequatorial mountains». Permafrost and Periglacial Processes, 1 (3/4), 249-263.

FrANCOU, B y HÉTU, B. (1989): «Eboulis et autres formations de pente heterometriques. Contribution a une terminologie geomorphologique».Notes et Comptes-Rendus du groupe de travail «Regionalisation du Périglaciaire». XIV, 11-69.

FrENCH, H.F. (2000): «Does Lozinski's Periglacial Realm Exist Today?A Discussion Relevant to Modern Usage of the Term 'Periglacial'». Permafrost and Periglacial Processes, 11 (1), 35-42.

FRENCH, H. (2007): The Periglacial Environment. Wiley y Sons, Chinchester.

García Ruíz, J.M.; VAlero, B.; GonzÁlez SAMPÉriz, P.; LOREnTE, A.; Martí Bono, C.; BegueríA, S. y EdwARdS, L. (2001): «Stratified Scree in the Central Spanish Pyrenees: Palaeo enviromental Implications». Permafrost and Periglacial Processes, 12 (3), 233-242.

Gengnian, L.; ZhiJIU, C.; DAOKAI, G. y YongQIU, W. (1999): «The Stratified Slope Deposits at Kunlunshan Pass, Tibet Plateau, China». Permafrost and Periglacial Processes, 10 (4), 369-375.

GuILliEN, Y. (1951): «Les grèzeslitées de Charente». Revue Géographique des Pyrénees et du Sud-Ouest, 22, 153-162.

GuILLIEN, Y. (1962): «Grave, Grèze, Gress». Bulletin de l'Association de Géographes Français, 303-304, 79-81. 
Guitián RiverA, L. y PÉREZ AlBERTI, A. (1992): «Biogeografía y procesos periglaciares en la Serra do Courel». In: Rodríguez Martínez-Conde, R. (Coord.), Guía de Campo de las VIII Jornadas de Campo de Geografía Física.Departamento de Xeografía. Universidade de Santiago de Compostela, 116 pp.

HARRIS, S.A. y PRICK, A. (2000): «Conditions of formation of stratified screes, slims River Valley, Yukon Territory: A possible analogue with some deposits from Belgium». Earth Surface Processes and Landforms, 25, 463-481.

HETU, B. (1995): «Le litage des ÉbouliesStratifiésCryonivaux en Gaspésie (Quebec, Canada): Rôle de la SédimentationNivéo-Éolienne et des TransitsSupranivaux». Permafrost and PeriglacialProcesses, 6 (2), 147-171.

Hetu, B.; VAn Steijn, H. y Bertran, P. (1995): «Le rôle des coulées de pierres sèches dans la genèse d'un certain type d'éboulies stratifiés». Permafrost and Periglacial Processes, 6 (2), 173-194.

JournauX, A. (1976): «Les grèzes du Châtillonnais». Bulletin de l'Association française pour l'étude du Quaternaire, 48-49, 123-138

KIRKBY, M.J. y STATHAM, I. (1975): «Surface stone movement and scree formation». Journal of Geology, 83 (3), 349-362.

LiNARES, J.A. (1984): Características climáticas de la Ciudad de Ushuaia y Zonas Adyacentes. Centro Austral de Investigaciones Cientificas. Ushuaia. Policopiado.

MALAURIE, J. y GUILliEN, J. (1953): «Le modelé cryonival des versants meubles de Skansen (Disko, Groenland). Interprétation général des grèzes litées». Bulletin de la Société Géologique de France, III, 703-721.

MenichetTI, M., Lodolo, E. y TASSONE, A. (2008): «Structural geology of the Fuegian Andes and Magallanes fold-and-thrust belt- Tierra del Fuego Island». Geologica Acta, 6 (1), 19-42.

NieuWEnhuiJzen, M. E. y VAN Steijn, H. (1990): «Alpine debris-flows and their sedimentary properties. A case study from the French Alps». Permafrost and Periglacial Processes, 1, 111-128.

Olivero, E.B. y Martinioni, D.R. (2001): "A review of de geology of de Fuegian Andes». Journal of South American Earth Sciences, 14 (2), 175-188.

Ozouf, J.C.; Coutard, J.P. y LAuTRIdou, P. (1995): «Grèzes, Grèzes Litées: Historique des Definitions». Permafrost and Periglacial Processes, 6 (2), 85-87.

Ozouf, J.C.; Coutard, J.P. ; Texier, J.P. y Bertran, P. (1993): «Grèzes Litées». Excursion du Colloque «Processus et depots periglaciaires de versant». Commission «Les Milieux periglaciaires» (U.G.I.), Groupe de travail des Processus et Environnements Periglaciaires (A.I.P.), Associaction Francaise du Pergelisol (A. F. P.), Charentes-Perigord.

PAPPALARDO, M. (1999): «Observations on stratified slope deposits, Gesso Valley, Italian Maritime Alps». Permafrost and Periglacial Processes, 10, 107-111.

PÉREZ AlBERTI, A. (1979): «Nuevas observaciones sobre glaciarismo y periglaciarismo en el NW de la Península Ibérica. La Galicia sudoriental». Acta Geológica Hispana. Homenage Ll. Solé Sabarís, 441-444.

PÉrez Alberti, A. (1982): «Xeomorfoloxía y Climatoloxía». In Pérez Alberti, A. (Dir.). A Xeografía de Galicia. Tomo I: O Medio. Ed. Sálvora. Santiago.

PÉREZ ALBERTI, A. (1993): «La interacción entre procesos geomorfológicos en la génesis del relieve del SE de Galicia: el ejemplo del Macizo de Manzaneda y de la 
Depresión de Maceda». In La evolución del paisaje en las montañas del entorno de los Caminos jacobeos. Consellería de Cultura de la Xunta de Galicia, Santiago de Compostela, 1-24.

PÉREZ ALBERTI, A. (2012): «La formación de depósitos estratificados de ladera en un clima frío marítimo (Andes de Tierra del Fuego, Argentina)». Nimbus, 29-30, 491-509.

PÉREZ Alberti, A.; Valcarcel, M.; Blanco ChaO, R.; Carrera, P.; Castillo, F., López Bedoya, J., CAlvo, R. y Macías, F. (2007): «Cartografía y monitorización de formas crionivales en la región subantártica (Tierra del Fuego, Argentina). Proyecto GEOSAP». Xeográfica, 7, 151-165.

Pérez Alberti, A.; Valcarcel, M.; Carrera, P.; Blanco ChaO, R. y López BEDOYA, J. (2008): «Movilidad de la capa superficial del suelo en los Andes fueguinos (Tierra del Fuego, Argentina)». In: BENAVENTE, J. y GRACiA, F.J. (eds.) Trabajos de Geomorfología en España: 2006-2008. Sociedad Española de Geomorfología/Universidad de Cádiz, 237-240.

PÉrez AlBerti, A.; LÓPez BedOyA, J. y CunHA, P.P. (2009): «Sedimentological analysis of cold-climate stratified slope deposits of Galicia, NW Iberia». 27th IAS Meeting of Sedimentologists, Book of Abstracts, Alghero, p. 311.

REDONDO, J.M. (2004): «El glaciar rocoso de Cerro Krund, Tierra del Fuego, Argentina». Cuadernos de Investigación Geográfica, 30, 169-180.

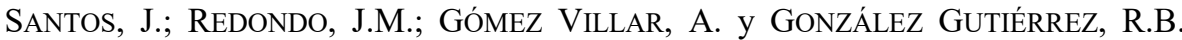
(2015): «Nuevas evidencias de la existencia de permafrost en Tierra del Fuego (Argentina): régimen térmico del glaciar rocoso activo del Cerro Krund». In MARCOS VAlCÁRCEL (Ed.), Aportaciones al conocimiento de los ambientes fríos (2009-2011), Monografías del Grupo de Investigación «Ciencia do Sistema Terra (GI-1553)-USC», Santiago de Compostela, pp. 37-53.

TEXIER, J.P. y MEIRELES, J. (2003): «Relict mountain slope deposits of northern Portugal: facies, sedimentogenesis and environmental implications». Journal of Quaternary Science, 18 (2), 133-150.

TUHKAMEN, S. (1992): «The climate of Tierra del Fuego from a vegetation geographical point of view and its ecoclimatic counteparts elsewhere». Acta Botanica Fennica, 145, 1-64.

Valcárcel, M.; Carrera, P.; Coronato, A.; CAStillo, F.; Rabassa, J. y PÉrez AlBerti, A. (2006): «Cryogenic landforms in the Sierras de Alvear, Fuegian Andes, Subantarctic Argentina». Permafrost and Periglacial Processes, 17 (4), 371376.

VAN Steijn, H.; VAn Brederode, L. y GoedHeER, G. (1984): «Stratified slope deposits of the grèze-litée type in the Ardèche Region in the South of France. Geografiska Annaler. 66, 295-305.

VAn Steijn, H.; Bertran, P.; Francou, B.; Hetu, B. y TeXier, J.P. (1995): «Models for the genetic and environmental interpretation of stratified slope deposits: review». Permafrost and Periglacial Processes, 6, 125-146.

VAN STEIJN, H. (2011): «Stratified slope deposits: periglacial and other processes involved». In MARTINI, I.P., FRENCH, H.M. Y PÉREZ AlBERTI, A. Ice-Marginal and Periglacial Processes and Sediments. Geological Society, 354, 213-226. 